\title{
ОСОБЛИВОСТІ ЕМОЦЙНОЇ СФЕРИ СТУДЕНТІВ ТЕХНІЧНОГО ЗВО З РІЗНИМ РІВНЕМ ПСИХОЛОГІЧНОЇ ЗРІЛОСТІ
}

Статтю присвячено проблемі психологічної зрілості особистості. Розглянуто основні теоретичні підходи до феномена зрілості особистості. Подано результати дослідження особливостей емочійної сфери студентів із різним рівнем психологічної зрілості.

Ключові слова: психологічна зрілість, особистісна зрілість, емочійна сфера.

The article is devoted to the problem of psychological person maturity. The main theoretical approaches to the phenomenon of person maturity are considered. The results of the research in the emotional sphere features of the students with different psychological maturity levels are presented.

Keywords: psychological maturity, personal maturity, emotional sphere.

Статья посвящена проблеме психологической зрелости личности. Рассмотрень основные теоретические подходы $\kappa$ феномену зрелости личности. Представленьл результаты исследования особенностей эмочиональной сферы студентов с разным уровнем психологической зрелости.

Ключевые слова: психологическая зрелость, личностная зрелость, эмочиональная cфepa.

Постановка проблеми. У пропонованій роботі звернення до проблеми психологічної зрілості особистості викликане зросталими тенденціями інфантилізації, примітивізації та поверховості мислення, мовлення, поведінки, спілкування, емоційної сфери й стосунків сучасної людини, які дуже легко фіксуються елементарним досвідом спостереження життя. У зв'язку з цим проблема зрілості в цей історичний період входить у зону підвищеної актуальності.

Поняття «зрілість» належить до вельми різних, хоча й пов'язаних явищ, що відображає недостатню наукову розробленість феномена зрілості як такого. Існує два найбільш поширених підходи до розуміння структури психологічної зрілості особистості. Згідно з першим підходом, поняття зрілої особистості можна описати такими властивостями, як синергетичність, автономність, відповідальність, контактність, самоприйняття, децентрація, толерантність, глибинність переживань, життєва філософія та креативність. Згідно 3 другим підходом, розглядають структурну модель психологічної зрілості особистості, яка складається 3 когнітивного, мотиваційного й поведінкового компонентів. Проте в цих підходах залишаються поза увагою особливості емоційної сфери [3; 9].

Незважаючи на досить широкий діапазон робіт, що стосуються різних аспектів зрілості, ми можемо констатувати швидше недостатню розробленість цієї тематики. По-перше, це стосується термінологічного й понятійного апарату. Має місце змішання понять і розуміння різних аспектів зрілості. По-друге, багато авторів в 
описових моделях зрілої особистості використовують близькі, схожі або просто ідентичні характеристики, проте вони виявляються досить розмитими й важко застосовними як критеріальний набір. Крім того, абсолютно не досліджено питання, які особливості притаманні емоційній сфері особистості. Це означає, що інформація про цю сферу залишається в зоні недостатньої ясності. Вищевикладене визначає необхідність більш детального як теоретичного, так і емпіричного дослідження вказаної тематики.

Аналіз останніх досліджень і публікацій. Поняття «зрілість» легко зіставляється 3 дослідженням екзистенціальних аспектів людського життя й функціонуванням свого «Я» в широкому сенсі до можливості вплинути на світ $\mathrm{i}$ змінити його, уписати себе в багатовимірний соціокультурний досвід, в універсум. Змістовне наповнення поняття зрілості особистості багато в чому визначено філософським аналізом таких явищ, як «втеча від свободи» (Е. Фромм), «екзистенція» (Ж. П. Сартр, К. Ясперс); «самоактуалізація» (А. Маслоу), «самість» (К. Г. Юнг), «соціальний інтерес» (А. Адлер), «життєвий сенс» (В. Франкл); «Его-інтеграція» (Е. Еріксон) та ін.

У традиційних для вітчизняної психології підходах зрілість розглядають із погляду іï значення для суспільства. Акцент роблять на властивостях, процесах, умовах становлення, цінностях, які свідчать про набуття людиною цього значення (Б.Г. Ананьєв, А.А. Бодальов, С.Л. Рубінштейн, Д.А. Леонтьєв, А.А. Реан, П.М. Якобсон, Л.І. Божович, А.Л. Журавльов та ін.). В українській психології глибокий аналіз проблеми психологічної зрілості особистості поданий у роботах О.С. Штепи, В.А. Роменця, В.А. Татенка, Т.М. Титаренко, Л.П. Овсянецької, I.П. Манохи та ін.

Під час онтогенезу зрілість постає критерієм і умовою успішного освоєння різних соціальних ролей, статусів, біологічно й соціально зумовлених функцій. Зрілість може виражати співвідношення рівня розвитку окремої людини з якимись загальними вимогами адаптації, розвитку й функціонування людей у конкретній соціальній системі.

Зрілість можна розглядати з погляду результату деякого розвитку. Б.Г. Ананьєв [1], диференціюючи лінії людського розвитку, запропонував як своєрідний підсумковий критерій кожної 3 них розуміти певний тип зрілості. Результатом розвитку людини в статусі індивіда $є$ досягнення фізичної (біологічної) зрілості; результатом розвитку психосоціальних якостей особистості - досягнення соціальної зрілості; результат розвитку людини як суб'єкта праці та іiі розумово-пізнавальної діяльності відображений у працездатності й розумової зрілості.

Розглядаючи зрілість (дорослість) із позицій генетичної психології, Б.Г. Ананьєв визначає їі як завершення процесу розвитку й реалізацію вже сформованих механізмів, властивостей і структур поведінки, закладених у дитинстві. На підставі цього випливає висновок: зрілість - стаціонарний стан, що характеризується повною стабілізацією функцій і властивостей сформованої особистості, що утворився 
інтелекту й визначеної ціннісної системи.

Згідно з визначенням С.Л. Рубінштейна, зріла особистість - це людина, здатна здійснювати рух не тільки «вперед», але і «вгору», до кращих проявів людської сутності й здатна самостійно визначати свій життєвий шлях, вибираючи й здійснюючи його напрямок: «Особистість сама визначає поворотні етапи життєвого шляху, прийняттям рішення і відповідно може визначати напрямок життя» [6].

Згідно з П.М. Якобсоном, психологічні риси зрілої особистості проявляються у вираженому прагненні до творчості (прояв творчого початку в найрізноманітніших сферах життя), інтелектуальній активності (у сенсі постановки життєвих проблем, готовності їх вдумливо зрозуміти й спробувати наполегливо вирішувати); достатній емоційній сенситивності, що має вибірковий характер; мобільності здібностей (уміння реалізовувати у відповідних діях властиві людині потенції, які вона бажає розкрити); рефлексії свого духовного «Я», яке служить завданням самоорганізації, цілями якої постають моральне самовдосконалення, інтелектуальне зростання, естетичний розвиток і багато іншого [10].

Для зрілої особистості характерними $є$ почуття відповідальності, потреба в турботі про інших людей, здатність до психологічної близькості з іншою людиною, здатність до активної участі в житті суспільства, система адекватних мотивів, стійкість характеру і почуттів.

Згідно $з$ Л.І. Божович, психологічно зрілою особистістю $є$ людина, здатна керуватися свідомо поставленими цілями. Ця здатність зумовлена розвитком трьох сторін особистості: раціональної, вольової та емоційної. Саме всебічний, гармонічний розвиток кожної людини і $є$ головною умовою народження особистості, що вміє самостійно визначати шлях свого життя, своє місце в ньому, свою справу, цікаву й важливу для всіх, у тому числі й для себе самої.

Проблематика особистісної зрілості в українській науці розроблялась у векторах: а) автентичності особистості як прагнення людини до самостворення через іiі здатність до вчинку (за В.А. Татенко) [7]; б) визначення рівнів особистісної зрілості, якими, за Л.А. Лєпіховою, є соціалізація і 31 соціально-психологічна компетентність; в) виділення психологічних рис зрілої особистості (Л.П. Овсянецька); г) аналізу динамічної особистісної структури, що детермінується певними механізмами, а іiі змістом є риси, які взаємоактивують одна одну (О.С. Штепа) [9]. Загалом серед психологічних показників особистісної зрілості можна виділити наступні: прагнення до самореалізації та творчості, здатність до самоаналізу й до розуміння інших, здатність до вибору, комунікативність, відповідальність.

Отже, психологічна зрілість визначається у вузькому сенсі як показник роботи сенсорних, мнемічних та інтелектуальних функцій людини; у широкому сенсі - як період свідомої регуляції людиною власної поведінки, який передбачає реалізацію людини як особистості. Зріла особистість характеризується розширеним чуттям власного Я, здатна з розумінням ставитися до довкілля, має чуття фундаментальної емоційної безпеки й прийняття себе, діє й думає відповідно до зовнішньої реальності, 
здатна до самооб'єктивації, розуміння себе, має почуття гумору, живе в гармонії 3 власною філософією життя [5].

Формування умов психологічної зрілості $є$ важливим завданням психічного розвитку в молоді. Реалізація цього стратегічного завдання залежить не тільки й не стільки від «зовнішніх» обставин життя (соціальної ситуації розвитку), але, головним чином, від «внутрішньої», суб'єктивної, прихованої від очей роботи особистості 3 перетворення себе в суб'єкта власного розвитку та свого життя в цілому.

Мета роботи - виявити особливості емоційної сфери юнаків і дівчат із різним рівнем психологічної зрілості.

Для дослідження особливостей емоційної сфери сучасних юнаків і дівчат 3 різним рівнем психологічної зрілості був використаний психодіагностичний інструментарій. У дослідженні взяли участь 87 юнаків і дівчат віком від 18 до 22 року, які є студентами Національного аерокосмічного університету ім. М.Є. Жуковського «XАI».

У результаті дослідження виявлено, що в юнаків і дівчат 3 високим рівнем психологічної зрілості в емоційному профілі переважали емоції інтересу й радості. Був діагностований помірний рівень особистісної тривожності й реактивної тривоги. Показники агресивності й ворожості дещо вищі за середні значення. Домінантним проявом агресії є вербальна форма. Рівень парціального емоційного інтелекту перебуває в зоні середніх значень, як і рівень інтегративний. Подібні дані свідчать про достатній розвиток емоційного інтелекту в студентів із високим рівнем психологічної зрілості.

У юнаків і дівчат з низьким рівнем психологічної зрілості провідними емоціями постають інтерес і радість, але разом із цим спостерігалися завищені показники за емоцією сорому. Для цієї групи досліджуваних характерні високі показники особистісної тривожності й реактивної тривоги, а також загального рівня агресивності, у той час як індекс ворожості перебуває в межах норми. Вербальна агресія домінує, проте високі результати спостерігаються й за шкалами негативізму та роздратування. Результати дослідження емоційного інтелекту вказують на низькі значення за всіма шкалами, які в сумі формують низькі інтегративні значення.

У групі юнаків і дівчат з високим рівнем психологічної зрілості, на відміну від другої групи, переважають більш високі значення за емоцією інтересу, шкалами «емоційна обізнаність», «керування власними емоціями», «самомотивація», «емпатія» й інтегральний показник емоційного інтелекту. Для групи юнаків і дівчат із низьким рівнем психологічної зрілості характерні більш високі значення за емоціями горя, гніву, сорому, а також шкалами «реактивна тривога», «особистісна тривожність», «негативізм», «почуття провини».

На підставі отриманих результатів дослідження можна зробити наступні висновки. За високого рівня психологічної зрілості юнаки й дівчата характеризуються більш високим рівнем пізнавальної активності, емоційною стабільністю, розвиненим емоційним інтелектом. Навпаки, юнаки й дівчата 3 низьким рівнем психологічної 
зрілості більш схильні до переважання в емоційному профілі негативних емоційних переживань, тривожності, негативізму й самозвинувачувальних реакцій.

\section{Література:}

1. Ананьев Б. Г. Человек как предмет познания. СПб. : Питер, 2001. 288 с.

2.Леонтьев Д. А. Личностная зрелость как опосредование личностного роста. URL : http://liber.rsuh.ru/Conf/ Psyh_razvitie/leontieu_2.htm.

3. Наумчик Н. В. Психологічна зрілість студентів у контексті актуальних проблем психологічної науки і практики // Особистість у просторі культури: Матеріали Всеукраїнського науковопрактичного симпозіуму. Севастополь : Рібест, 2009. С. 88-91.

4. Оллпорт Г. Становление личности: Избранные труды. М. : Смысл, 2002. 462 с.

5. Реан A. A. Личностная зрелость и социальная практика. Теоретические проблемы психологии. СПб., 1995. С. 34-39.

6. Рубинштейн С. Л. Бытие и сознание. Человек и мир. СПб. : Питер, 2003. 512 с.

7. Татенко В. О. До проблеми автентичності людського буття: вчинкові парадигма. URL : http://politicon. iatp.org.ua

8. Титаренко Т. М. Життєвий світ особистості: у межах і за межами буденності. Київ : Либідь, 2003. $376 \mathrm{c}$.

9. Шmеna О. С. Особистісна зрілість: Модель. Опитувальник. Тренінг : монографія. Львів : Видавничий центр ЛНУ імені Івана Франка, 2008. 210 с.

10. Якобсон П. М. Психологические компоненты и проекции становления зрелой личности. СПб. : Изд-во «Питер», 2000. 193 с.

\section{Natalia Kalaytan, Amalia Makarenko, Tatiana Starovoit}

\section{FEATURES OF EMOTIONAL SPHERE OF STUDENTS OF TECHNICAL HIGHER EDUCATION WITH DIFFERENT LEVELS OF PSYCHOLOGICAL MATURITY}

The article is devoted to the problem of psychological maturity of the individual. The basic theoretical approaches to the phenomenon of maturity of the person are considered.

The concept of «maturity» correlates with the study of existential aspects of human life and is considered from the point of view of its significance for society. In the course of ontogeny, maturity acts as a criterion and a condition for the successful development of various social roles, statuses, biological and socially determined functions. Psychological maturity is defined in the narrow sense as an indicator of the work of sensory, mnemonic and intellectual functions of a person; in the broad sense - as a period of conscious regulation by a person of his own behavior, which involves the realization of man as a person.

There are two main approaches to understanding the structure of psychological maturity of the individual. According to the first approach, the concept of mature personality can be described by such properties as synergy, autonomy, responsibility, 
contact, self-acceptance, decentralization, tolerance, depth of experiences, life philosophy and creativity. According to the second approach, the structural model of the person's psychological maturity, which consists of cognitive, motivational and behavioral components, is considered. Formation of conditions for psychological maturity is an important task for mental development in youth.

The article presents the results of studying the features of emotional sphere of students with different levels of psychological maturity. In the group of boys and girls with a high level of psychological maturity, emotional profiles dominated the emotions of interest and joy. Moderate levels of personal anxiety and reactive anxiety were diagnosed. Indicators of aggressiveness and hostility are slightly higher than average values. The dominant man infestation of aggression is a verbal form. Sufficient development of emotional intelligence for students with a high level of psychological maturity is revealed.

In boys and girls with a low level of psychological maturity, the main emotions were interest, joy and shame. High levels of personal anxiety and reactive anxiety are revealed, as well as the general level of aggressiveness. The results of the study of emotional intelligence indicate low values for all scales, which in sum form the low integrative values.

At a high level of psychological maturity, boys and girls are characterized by a higher level of cognitive activity, emotional stability, and developed emotional intelligence. On the contrary, boys and girls with a low level of psychological maturity are more likely to prevail in the emotional profile of negative emotional experiences, anxiety, negativism and selfinducing reactions.

Калайтан Наталія Леонтіївна - кандидат психологічних наук, доцент, доцент кафедри психології гуманітарного факультету Національного аерокосмічного університету ім. М.Є. Жуковського «XАI».

e-mail: n.kalaytan@khai.edu

Макаренко Амалія Олексіївна - кандидат психологічних наук, доцент, доцент кафедри психології гуманітарного факультету Національного аерокосмічного університету ім. М.С. Жуковського «XАI».

E-mail: makarenko.amaliya@gmail.com

Старовойт Тетяна Павлівна - кандидат психологічних наук, доцент кафедри психології гуманітарного факультету Національного аерокосмічного університету ім. М.Є. Жуковського «XAI».

e-mail: tatyana.starovoyt@gmail.com 
Надійшла до редакції 14.05.2018. Розглянута на редколегії 25.06.2018.

\section{Рецензенти:}

Доктор філософських наук, професор, професор кафедри філософії Національного юридичного університету імені Ярослава Мудрого Дзебань А.П.

Доктор філософських наук, професор, декан гуманітарного факультету Національного аерокосмічного університету ім. М.С. Жуковського «ХАI» Копилов В.О. 